\title{
Regional Toponymy in Cirebon Regency: An Ethnolinguistic Study
}

\author{
Nani Darheni \\ Language Center of West Java \\ Language Agency \\ nanikinanti71gmail.com,nani_darheni07@yahoo.com
}

\begin{abstract}
Cirebon is one of the most interesting regions in Indonesia and has three center of kingdoms which are widely recognized in the history of Cirebon, namely Kasepuhan, Kanoman, and Kecerbonan Palace (Ramlan, 2008: 11). Cirebon is also a center for the development of various aspects of life, such as economy, politic, culture, history, as well as religion with various ethnics and religious backgrounds. One of the indicators of community sociocultural development in Cirebon is the practice of naming a place (toponym). Toponym is a form of linkage between language, culture, and mindset of its people. The concept of regional toponym reflects the sociocultural and historical paradigm of its owner community. This study aims to: (1) explain the underlying aspects of toponym; (2) describe the morphological form in toponym; and (3) reveal the philosophy/values of local wisdom from the toponym system in the district and city of Cirebon. The method used is descriptive-qualitative and ethnography with explorative technique and ethnolinguistic approach. The data source derive from the name of the village, urban village, and subdistrict located in the district and city of Cirebon, in the form of (a) written sources/literature study and (b) oral/informant, which consists a number of humanists, historians and public figures. The Research instruments used are descriptive questionnaire list, structural observation sheet, and ethnographic interview. The Toponym in the district and the city of Cirebon is in the form of: (a) the underlying aspects, for instance geographical, historical, and cultural (castles-centered/non castle-centered); (b) the form of words, phrases, idioms and categories such as maritime, names of trees, fruits, historical figures, nature, geography, hydrology, job of figures, origin/events that occur in society, functions, and others; (c) the philosophy of life in the form of comprehensive patriotism/ancestral and grateful, live on the move, move forward, and many more.
\end{abstract}

Keywords: Toponym, village/urban village, ethnolinguistic.

\section{INTRODUCTION}

Cirebon is one of the most interesting regions in Indonesia which once had a glorious empire in its time and now still becomes a historical center with three widely recognized kingdom centers in the history of Cirebon, covering Kasepuhan, Kanoman, and Kecerbonan (Ramlan, 2008: 11). Cirebon is also a center for the development of various life aspects, including economic, political, cultural, historical, and religious aspects with various ethnic and religious backgrounds.

Cirebon is located at the eastern part of the north coast of West Java. Regarding to the cultural perspective, Cirebon is one interesting phenomenon which draws a lot of people's attention from various social levels. Cirebon cultural universal communication (Unicom) has become its people's characteristics until now due to the geographical and historical factors, as stated by Wahidin (2006). In this context, as a coastal area, Cirebon, either before or after influenced by Islam, is one important port in the north coast of Java that it is a greatly open for the cultural interactions which are eventually widespread and internalized that Cirebon becomes a melting pot area, where various ethnics and religions among nations meet. Furthermore, in social context, Cirebon people are culturally composed of various ethnic groups from Sundanese, Javanese, Sumatrans, Peninsular, Indian, Persian, Syrian, Arabic, and Chinese that the logical consequences of such plural communities present acculturation processes of culture and syncretism which become the unavoidable necessity.

This cultural diversity is mutually mixed and completing each other that our naked eyes may see the influence of Hinduism-Buddhism, Chinese, Islam, and the western countries, in addition to the existence of the ancestral (primordial) culture simultaneously unites to form a unique civilization structure. This is how the construction of Cirebon cultures is initially built. The touch of the demographically diversed primordial cultural genetics plays a significant role in the formation of its characteristics and simultaneously results in a hybrid cultural tendency.

One Cirebon cultural hybridity phenomenon is its language. This is obviously seen from its people's communication system that Cirebon language is a mixture of Sundanese, Arabic, Bugis, Chinese, Malay, and Javanese. Language is an oral and written communication device used by the communities.

In Cirebon, one aspect which becomes an indicator of its communities' socio-cultural conditions, especially the language is the naming practice (onomastics). The naming practice reflects the psychological condition of Cirebon's people in macro level, which further reflects the people's thinking structure that eventually such mindset may contribute to the sociocultural structure of Cirebon's communities in a more practical level. The naming practice may also become one ideological indicator of a community group which includes the values (good/bad and inappropriate/inappropriate), beliefs, and hopes that the given name is in accordance with the people's demands during and/or after the creation of a given name.

Anthropolinguistics or etnolinguistics is a science investigating the relationship of different linguistic uses 
with the specified cultural patterns in the society or a science which tries to find the relationship between languages, linguistic and cultural uses in general. Ethnology learns the relationship between language and the ethnical factors. [1] states that ethnolinguistics is a linguistic branch investigating the relationship between language and rural communities or those have not yet writing or linguistic branch investigating the relationship between language and the linguists' attitudes towards language. The other sources mention that ethno-linguistic is a science discussing the characteristics and grammatical patterns of various tribes and their distributions.

Culture or anthropology serves as a description or modifier. Thus, linguistic anthropology is more appropriate if classified as a linguistic branch of anthropology because its main descriptive target is language (form, function, and meaning). This is in accordance with an idea proposed by Foley (1997). He explains that linguistic anthropology is a subordinate of linguistic field related to a linguistic site in a broader social and cultural context which plays a significant role in shaping and maintaining the cultural practices and social structures. Ethno-linguistics is one branch investigating the relationship between language and rural communities or societies who have no writing yet (this field is also called linguistic anthropology). The branch of linguistic anthropology investigates the relationship of language and linguists' attitudes towards language. One most prominent ethno-linguistic aspect is a problem dealing with the linguistic relativity.

Linguistic anthropology is a theory which acknowledges the expression and situational level as the meaning determinant factor. The followers of this theory gain their inspirations from the researches in the field of anthropology. Sapir-Whorf (1965) explains their linguistic relativity theory that there is a relationship between language, culture, and humans' logical thinking that according to Sapir-Whorf, culture is resulted from the humans' logical thinking power manifested in language. Furthermore, this linguistic relativity theory states that people speak in different ways. They think differently because language offers different ways of expressing (meaning) the world around them. This theory asserts that the culture developed in society is manifested in its linguistic aspects, for example the constantly used linguistic structures may influence the way one thinks and behaves. Sapir and Whorf (1965) have a hypothesis known as the Sapir-Whorf Hypothesis which argues that language not only determines the cultural styles but also the humans' ways of thinking that culture is manifested in linguistic aspects. Thus, the human culture is manifested in linguistic aspects (in this case the toponymical system in Cirebon Regency.

\section{METHOD}

This research employs a descriptive-qualitative method based on the data of phenomena existing in communities to achieve understanding, knowledge, and the depiction of (historical) origins of regional toponymy (such as kampong, hamlet, village, administrative village [kelurahan], and district) located in Cirebon regency to describe the Cirebon linguistic form/structure and palace cosmology influence on the toponymy practice in Cirebon Regency and City.

Research method is how to conduct a research. This research employs a descriptive-qualitative method. Meanwhile, the research technique is a follow-up of the research method implementation based on a descriptivequalitative method (Sudaryanto, 2015) and the implementation of gradually advancing method (ethnographic method) proposed by Spradley (2013). The research techniques include (a) data collection method and techniques as well as (b) data processing (data analysis) method and techniques.

Thus, this research employs a qualitative method with an ethnographic approach to collect the data (in the form of regional/geographical/area names in Cirebon) as the lingual units of linguistic expressions based on the sociocultural context of communities in Cirebon. This method is derived from a new stream of the cognitive anthropology or ethnographic science or new/modern ethnography. Furthermore, in modern ethnography, the social and cultural forms of society are constructed or described through the ethnographic analysis and intuitive consideration from the researchers.

Based on the historical, geographical, and cultural aspects, the toponymical and morphological constructs, due to the authors' prior knowledge, have never been comprehensively investigated. This research aims at describing the toponymic morphological constructs in the areas of Cirebon Regency, West Java Province.

\section{RESULT}

\section{Toponymy Aspect}

Based on the historical aspects, Cirebon which is located on the eastern part of the north coast of West Java, regarding to the cultural perspective, is an interesting phenomenon which draws a lot of people's attention from various social levels. Thus, that Cirebon is a greatly open for the cultural interactions which are eventually widespread and internalized that Cirebon becomes a melting pot area, where various ethnics and religions among nations meet. Historically, the toponymy or naming of Cirebon or Nagara Gede (Garage; Grage) or Puser Bumi (earth belly button) was once a very sovereign area, especially during the reign of Susuhunan Jati or Sunan Gunung Jati or Susuhunan Cirebon before the collapse of Pajajaran Kingdom. Thus, Cirebon is a large sovereign state in West Java. In fact, the Wali (Islamic Holy Men) affirm that during the governance, Sunan Gunung Jati was considered as an Islamic panatagama enforcer throughout Sundanese region, domiciled in Caruban/Cerbon (Pakungwati) as a substitute for the late Sheikh Nuruljati.

The geographical and historical aspects are used to show the location of people's communities in particular regions, such as in Cirebon. The phenomenon appears in the naming of toponymy (kampong, hamlet, village, district, and kawedanan) by promoting: 
(1) Physical characteristics (topography) of a region, such as the name of river, lake, or pond: Kalitanjung, Kedung Menjangan, Teluk Agung, Sindanglaut, Kalibaru, Bojong Wetan, Situgangga, Tukmudal, and Susukan;

(2) Flower Names: Cihanjuang, Flamboyan, Kampung Melati, Bakung Kidul, and Bakung Lor;

(3) National hero name; Mandala;

(4) Water elements; Ciwaringin, Cisaat, Ciuyah, and Tukmudal;

(5) Culinary; Bandengan, Kadongdong, and Brondong;

(6) Names of fruit: Jamblang/juwet, Mundu Pesisir, and Dukupuntang;

(7) House yard/position/place names; Tegalgubug dan Lawanggada;

(8) Historical place names; Kanoman, and Sunyaragi;

(9) Tree or plant names: Jatiseeng, Gempol, Beringin, and Pasuketan;

(10) Animal names: Singaraja, Singalodra, and Gabus Wetan;

(11) Royal/public figure names; Cakrabuana, Syech Dahtul Kahfi, Sunan Gunung Djati, and Nyi Mas Gandasari.

\section{Morphological Forms}

Morphologically, the toponymy names of villages or sub-district in Cirebon Regency are described as follows.

\section{(a) Zero Derivation}

Zero derivation is a morphological process which does not change its form. The form before experiences a derivational process is the same with that after experiencing the derivation process. It is shown in the following data.

(1) Babadan village; has a zero derivational process, that is, Babadan + zero derivation --- Babadan.

(2) Kempek village; has a zero derivational process, that is, Kempek + zero derivation --- Kempek.

\section{(b) Affixation}

Affixation is a morphological process which changes the form. The basic form changes that it is not the same with the final form. The affixation of the village names in Kabupaten Cirebon is described in the following forms.

(1) Suffix-an

The allomorph $\{-a n\}$ is contained in Babakan village name; which means the tree which is injured and the result is called Babakan.

(2) Confix $\{p a--a n\}$

The toponymy with $\{$ pa--an $\}$ morphological form is found in the following examples.

Pabedilan village. Pabedilan: $\{p a--a n\}+$ bedil 'a weapon' that Pabedilan (categorized into noun) is an 'area or forest or place for hunting, in Sundanese bebedil 'hunting' (is categorized into verb).

Pasuruan village. Pasuruan: $\{p a--a n\}+$ suru 'cotton' that; (1) Pasuruan is derived from the word suru (cotton) from the cotton garden that Pasuruan means' a betel leaf to accompany the betel nut chewing and (2) Pasuruan is morphologically derived from the word suru which obtains the prefix of pe-and the suffix -an, to show a place, that Pasuruan means the hiding place for Putri
Asah and Putih Asih from the pursuit of Majapahit Kingdom enemy.

\section{(c) Abbreviation}

Abbreviation is a morphological process which changes its form and basic form shortened. It is shown in the following example.

(1) Trusmi village: Trusmi is derived from the shortening process of Terus + bersemi; The name of Trusmi Village experiences an abbreviation process, that is, always tumbuh (growing) + bersemi (sprouting) that gradually in the hamlet was called Trusmi which means 'terus bersemi (always sprouting)".

(2) Winong village; awi + naon --- Winong; Winong village name is derived from the word awi 'bamboo' which is shortened to wi and the word naon 'what' sounded with nong 'what' that it is shortened into winong.

(d) Composition;

Composition is a combination of two words or more.

(1) Bojong Gebang; bojong + gebang --- the composition of Bojong Gebang. Bojong village name is formed from a merging process of the word bojong (Sanskrit 'padukuhan [hamlet]') and gebang (Gebang is a name of area).

(2) Sindangkerta; sindang + kerta --- Sindangkerta. Sindangkerta word is derived from the combination of the word sindang which means 'come, drop in, spring and source' and kerta means 'fertile and prosperous'.

\section{CONCLUSION}

The toponymy found in the areas of Cirebon Regency is in the form of: (a) the underlying aspects, including geographical, historical, and cultural aspect (royal palace centrist/non royal palace centrist), (b) hierarchy, and (c) (morphological) forms in the form of words, phrases, idioms while the categories are in the form of maritime, names of trees, fruit, historical figures, natural/geographic conditions, hydrology, characters' work, the origin/events taking place in the society, and its functions.

\section{REFERENCES}

[1] Kridalaksana, Harimurti. Beberapa Prinsip Perpaduan Leksem dalam Bahasa Indonesia. Yogyakarta: Kanisius. 1983.

[2] Foley, William A. Anthropologycal Linguistics. Massacusetts: Balckwell Publisher Inc. 1997.

[3] Sudaryanto. Metode dan Aneka Teknik Analisis Bahasa: Pengantar Penelitian Wahana Kebudayaan Secara Linguistis. Yogyakarta: Sanata Dharma University Press. 2015.

[4] Spreadley, James P. The Ethnographic Interview. Diterjemahkan oleh Misbah Zulfa Elizabeth. Yogyakarta: Tiara WacanaYogya. 2013.

[5] Whorf, B. Language, Thought, and Reality: Selected Writings of Benjamin Lee Whorf. Cambridge, MA: The massachussetts Institute of Technology Press. 1956.

[6] Duranti, Alessandro. Linguistic Antropology. Cambridge: Cambridge University Press. 1997. 